TAPROBANICA, ISSN 1800-427X. April, 2009. Vol. 01, No. 01: pp. 66-73.

(C) Taprobanica Nature Conservation Society, 146, Kendalanda, Homagama, Sri Lanka.

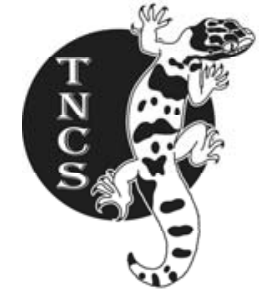

\title{
SOCIAL BEHAVIOURS OF CAPTIVE Trachypithecus cristatus (MAMMALIA: CERCOPITHECIDAE) IN THE NATIONAL ZOOLOGICAL GARDENS OF SRI LANKA
}

Submitted: 08 January 2009, Accepted: 11 January 2009

\author{
A. A. Thasun Amarasinghe ${ }^{1,2}$, W. Madhava S. Botejue ${ }^{1}$ and Lee E. Harding ${ }^{3,4}$ \\ ${ }^{1}$ Taprobanica Nature Conservation Society, 146, Kendalanda, Homagama, Sri Lanka \\ ${ }^{3}$ SciWrite Environmental Sciences Ltd. 2339 Sumpter Drive, Coquitlam, British Columbia, Canada \\ Corresponding authors: ${ }^{2}$ aathasun@gmail.com; ${ }^{4}$ harding@sciwrite.ca
}

\begin{abstract}
Trachypithecus cristatus (Silvered Leaf Monkey or Silvered Lutung) occur on the Malay Peninsula, Sumatra, Borneo and nearby islands and live mainly in uni-male, female-bonded groups. This study presents preliminary data on social behaviours for Silvered Leaf Monkey in captivity. Behavioural observations were conducted on one group (one adult male, four adult females, three juvenile males and four juvenile females). Data were collected on 30 of the 60 calendar days at the National Zoological Gardens, Dehiwala, Sri Lanka. All behaviours including agonistic and dominance-related, locomotion, feeding and infant-related behaviours were included in the analysis. Unlike in wild populations, we found a clear dominance hierarchy among females.
\end{abstract}

Key words: Trachypithecus cristatus, Captive Behaviour, Dominance, Hierarchy, Langur, Sri Lanka.

\section{Introduction}

Lutung, Langur, Leaf Monkey and Surili are common names for certain Asian and East Indian long-tailed, slender monkeys in the genera Trachypithecus, Semnopithecus and Presbytis. Lutung and Surili are Malay words that apply to the Southeast Asian genera Trachypithecus and
Presbytis, respectively, and may be preferable to Langur, a Hindi word that should perhaps be restricted to Semnopithecus, a mainly south Asian genus (Bernstein 1968; Brotoisworo 1979; Geissmann et al., 2004; Osterholtz et al., 2008; Weitzel \& Groves 1985). All have heavy eyebrows 